\title{
Antenatally diagnosed renal tumor: Questions
}

\author{
Wiebke Solass ${ }^{1} \cdot$ Hyunkyu Shin ${ }^{1} \cdot$ Cristian Urla $^{2} \cdot$ Andreas Schmidt $^{2}$ (I) \\ Received: 4 October 2020 / Accepted: 4 November 2020 / Published online: 9 December 2020 \\ (C) The Author(s) 2020
}

Keywords Renal tumor $\cdot$ Prenatal diagnosis $\cdot$ Pediatric neoplasm $\cdot$ Nephrectomy

\section{Case study}

During a routine ultrasound examination in the 37 th week of gestation, a tumor mass was diagnosed in the upper left abdomen of a female fetus. Since an allocation to an organ was not possible and for further diagnosis, a fetal MRI was performed, which revealed a solid mass in the upper pole of the left kidney. The course of the pregnancy was otherwise uneventful. The mother's medical history and the family history were unremarkable; there was no evidence of any abuse of noxious substances during pregnancy. The baby was born spontaneously in the 41st week of gestation without any other signs of abnormality; the physical examination was normal, and laboratory tests were within normal range.

Postpartum ultrasonographic and MRI examinations showed a solid tumor $(35 \times 27 \mathrm{~mm})$ in the upper pole of the left kidney (Fig. 1). Compared to the other

The answers to these questions can be found at https://doi.org/10.1007/ s00467-020-04857-0.

\section{Andreas Schmidt}

andreas.schmidt@med.uni-tuebingen.de

1 Institute of Pathology and Neuropathology, University Hospital Tuebingen, Eberhard-Karls University Tuebingen, Liebermeisterstr. 8, Tuebingen 72076, Germany

2 Department of Pediatric Surgery and Pediatric Urology, University Children's Hospital Tuebingen, Eberhard-Karls University Tuebingen, Hoppe-Seyler-Str. 3, 72076 Tuebingen, Germany kidney, the upper calyx group could not be clearly delineated. Compression or infiltration of adjacent structures was not detected. The laboratory tests revealed normal values for renal function (Table 1).

After interdisciplinary discussion and additional consultation of the renal tumor study board regarding nephron-sparing surgery, the decision was made to perform a tumor nephrectomy. On day 20 after birth, a laparoscopic tumor nephrectomy was performed.

Macroscopically, the cut surface in the upper pole of the 16-g left kidney had a gray-tan to white appearance. The tumor tissue was poorly demarcated from the surrounding tissues (Fig. 2). The microscopic examination displayed kidney parenchyma with minimal chronic inflammatory infiltrates, merging into a lesion composed of bundles of spindle cells with no to mild atypia and islands of metaplastic cartilage. Immunohistochemical staining for Wilms Tumor-Gene 1 (WT1) showed nonspecific cytoplasmic staining, and no nuclear staining (Fig. 2).

The postoperative course was uneventful, and the baby was discharged 5 days after surgery in good clinical condition and with normal renal function.

\section{Questions}

Taking into account the antenatal diagnosis, as well as radiological and histopathological examinations of the tumor, what is the most probable type of tumor and which differential diagnosis has to be considered? 
Fig. 1 Postpartum (a)

The studies show a solid tumor in the upper pole of the left kidney. The upper calyx group cannot be clearly delineated 19th day after birth ultrasonography and (b) MRI

Table 1 Laboratory results at the
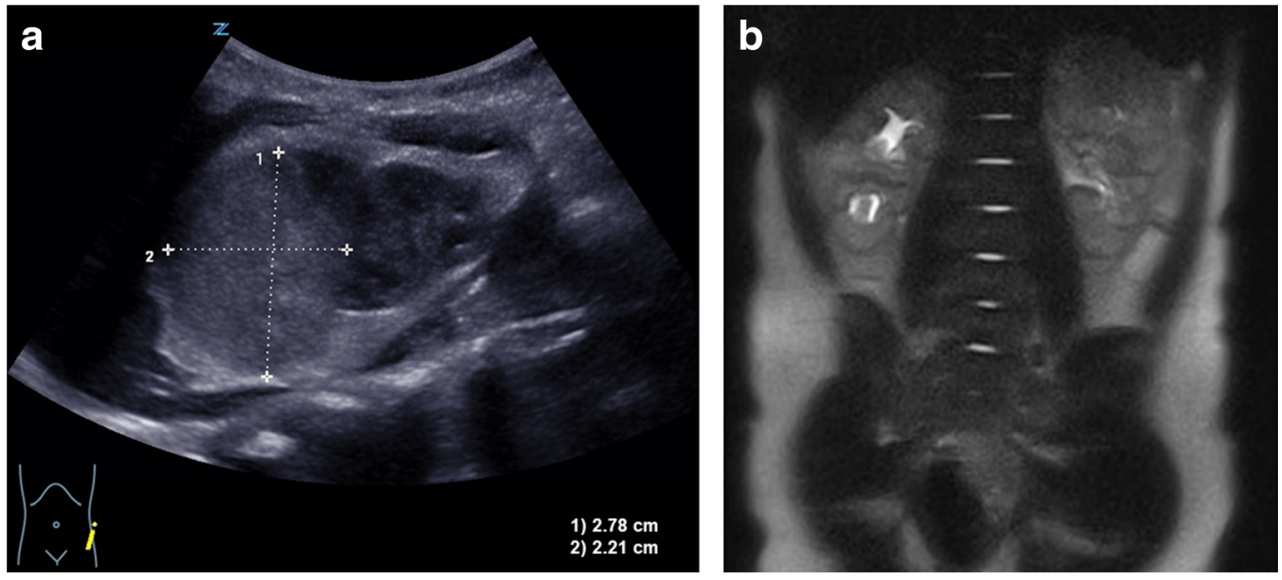

\begin{tabular}{llll}
\hline Laboratory blood test & Value & Reference range & Unit \\
\hline RBC & 4.39 & $3.0-5.4$ & $\times 10^{6} / \mu \mathrm{l}$ \\
Hematocrit & 42.3 & $42-62$ & $\%$ \\
Hemoglobin & 15.2 & $12.7-18.7$ & $\mathrm{~g} / \mathrm{dl}$ \\
WBC & 13,430 & $8300-14,700$ & $1 / \mu$ \\
Sodium & 138 & $136-148$ & $\mathrm{mmol} / 1$ \\
Potassium & 5.2 & $3.4-4.8$ & $\mathrm{mmol} / 1$ \\
Calcium & 2.7 & $2.1-2.6$ & $\mathrm{mmol} / 1$ \\
Phosphorus, inorganic & 2.5 & $1.3-1.8$ & $\mathrm{mmol} / 1$ \\
Creatinine & 0.3 & $0.2-0.6$ & $\mathrm{mg} / \mathrm{dl}$ \\
Urea & 21 & $15-50$ & $\mathrm{mg} / \mathrm{dl}$ \\
Protein total & 5.1 & $6-8$ & $\mathrm{~g} / \mathrm{dl}$ \\
C-reactive protein & 0.01 & $\leq 0.05$ & $\mathrm{mg} / \mathrm{dl}$ \\
\hline
\end{tabular}
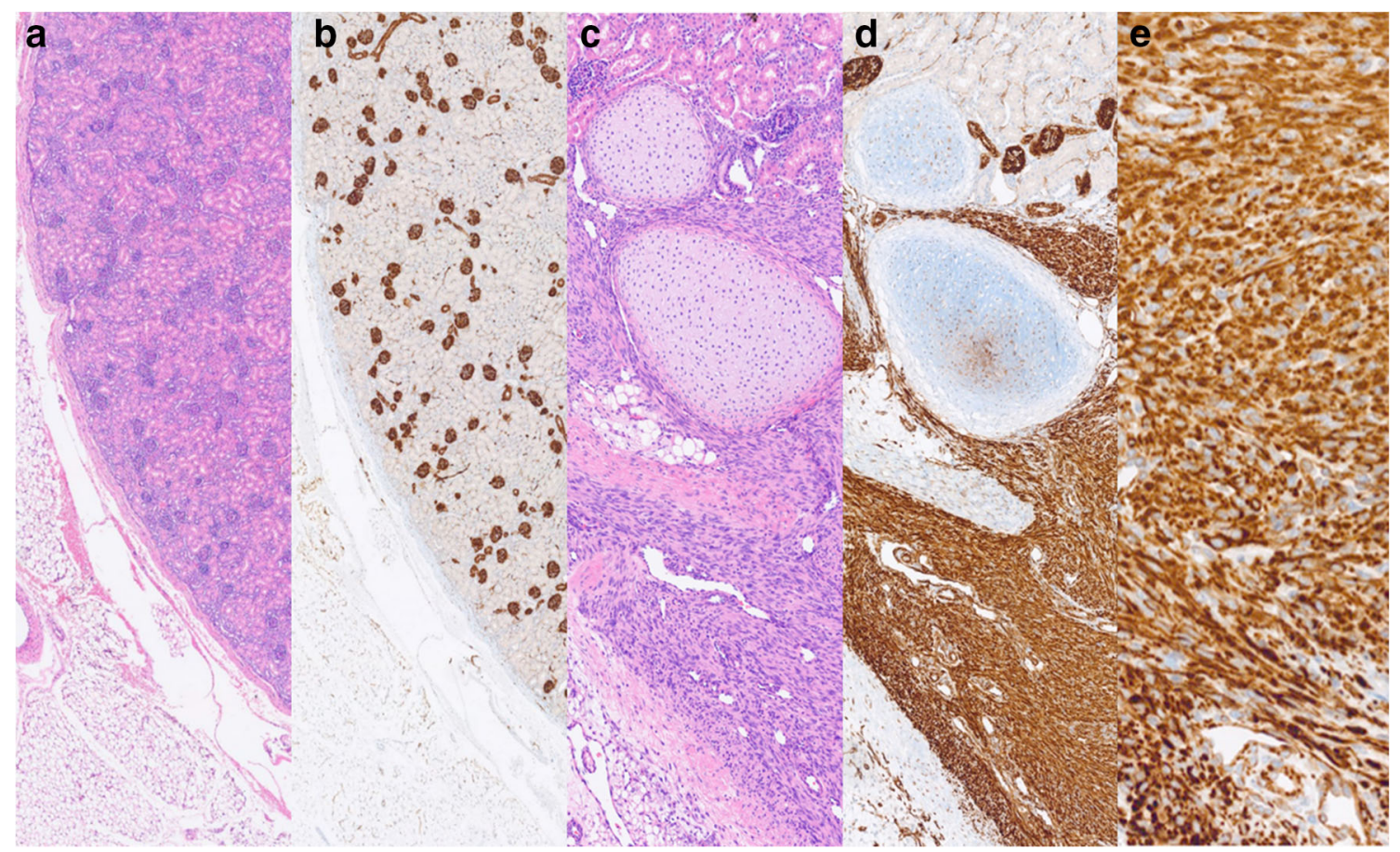

Fig. 2 (a), (b) H\&E and WT1 stain of the normal kidney parenchyma in comparison to the tumor mass $(\mathbf{c}-\mathbf{e})$. (c) An overview of the lesion with spindle cell proliferation at the periphery and metaplastic cartilage $(\mathrm{H} \& \mathrm{E}$

stain). (d) The same magnification and staining with WT1 which displays only a cytoplasmatic staining. (e) WT1 stain $(\times 100$ magnification) 
Funding Open Access funding enabled and organized by Projekt DEAL.

\section{Compliance with ethical standards}

Conflict of interest The authors declare that they have no conflicts of interest.

Consent for publication Written informed consent for publication of the clinical details and clinical images was obtained from the parents of the patient. A copy of the consent form is available for review by the Editor of this journal.

Open Access This article is licensed under a Creative Commons Attribution 4.0 International License, which permits use, sharing, adaptation, distribution and reproduction in any medium or format, as long as you give appropriate credit to the original author(s) and the source, provide a link to the Creative Commons licence, and indicate if changes were made. The images or other third party material in this article are included in the article's Creative Commons licence, unless indicated otherwise in a credit line to the material. If material is not included in the article's Creative Commons licence and your intended use is not permitted by statutory regulation or exceeds the permitted use, you will need to obtain permission directly from the copyright holder. To view a copy of this licence, visit http://creativecommons.org/licenses/by/4.0/.

Publisher's note Springer Nature remains neutral with regard to jurisdictional claims in published maps and institutional affiliations. 